\title{
Online Retailing: Purchasing Behaviour of Croatian Consumers
}

\author{
Matea Matic, PhD \\ Assistant Professor, University of Dubrovnik, Department of Economics and Business Economics, Croatia \\ E-mail:matea.matic@unidu.hr \\ Katija Vojvodic, PhD \\ Assistant Professor, University of Dubrovnik, Department of Economics and Business Economics, Croatia \\ E-mail: katija.vojvodic@unidu.hr
}

\section{Doi:10.5901/mjss.2013.v4n3p701}

\begin{abstract}
As regards the specific nature of electronic retailing, it is of the utmost importance for online retailers and marketers to better understand online consumers' behaviour. In that context, the issue of purchasing behaviour of Croatian consumers is a rather under-researched area. Therefore, the main aim of the paper is to determine the influence of impulsiveness on consumers' attitudes and intentions towards online purchasing. The data was collected through survey questionnaire using the purposive sample of 240 Croatian consumers from the Dubrovnik-Neretva County. Research results indicate that Croatian online consumers are influenced by the two major factors, impulsiveness and recreational factor. On the one hand, a moderately weak correlation was found between the impulsiveness factor and consumers' attitudes towards online purchase. On the other hand, a moderately strong correlation was found between the recreational factor and consumers' intentions and attitudes towards online purchasing. Hence, the recreational factor was determined to play a significant role in predicting consumer' attitudes and intentions towards online purchase.
\end{abstract}

Keywords: electronic retailing; online purchasing behaviour; online purchase intentions; Croatian consumers.

\section{Introduction}

The issue of e-retailing has attracted substantial research interest in recent years. The world over, e-retailing is the fastest growing segment in e-commerce today (Bhasker, 2006). The definition of e-retail includes all e-commerce activities that result in transactions with end consumers (Dennis et al., 2004). In that context, electronic retailers are using technology to convert "touch-and-feel" attributes into "look-and-see" attributes (Weitz, 2010). In doing so, marketers offering Web-based shopping typically try to provide a convenient, safe, and pleasant online environment, appropriate to addressing shoppers' functional goals (Bridges \& Florsheim, 2008). Moreover, e-store design and e-store navigation are proven to be significant stimuli of shopping enjoyment (Floh \&, Madlberger, 2013). It is often stated that Internet consumers are principally motivated by convenience. Rohm and Swaminathan (2004) argue that convenience is probably the most important perceived benefit from shopping on the Internet and a key factor influencing the growth of online shopping. It is mainly related to saving time and effort and flexibility in the timing for shopping. On the other hand, Kau et al. (2003) outline that in spite of the convenience of Internet shopping, consumers are still wary of shopping online. Consequently, online initial trust and familiarity with online purchasing have a positive impact on purchase intention (Chen \& Barnes, 2007).

As regards attitude, it is often seen as an antecedent variable, and motivation variables have a significant causal relationship with information search variables (Vazquez \& Xu, 2009). Shim et al. (2001) emphasize that consumers' attitudes towards online shopping affect consumers' intention to use the Internet for information search and, consequently, influence their intention to use the Internet for purchasing. In their research, van der Heijden et al. (2003) examine online purchasing intention using two different perspectives: a technology-oriented perspective and a trustoriented perspective. They assert that the trust-antecedent 'perceived risk' and the technology-antecedent 'perceived ease-of-use' directly influence the attitude towards purchasing online. According to Salo and Karjaluoto (2007), the actual outcome of trust-enhancing methods in online environments should be the development of long-term trusted customer relationships. In the context of online shopping, the findings suggest that attitudes toward online shopping and online shopping intentions are not only affected by ease of use, usefulness, and enjoyment, but also by exogenous factors like 
consumer traits, situational factors, product characteristics, previous online shopping experiences, and trust in online shopping (Monsuwe et al., 2004). Additionally, Martin and Herrero (2012) outline that online purchase intention is influenced by performance expectancy, effort expectancy, and users' innovativeness. In that context, they assert that innovativeness has a moderating effect on the relationship between performance expectancy and online purchase intention.

Impulsive buying behaviour refers to the tendency of consumers to make a purchase spontaneously, instantaneously and without prior consideration. Hedonism is often associated with the impulsivity in buying behaviour. In their study, Park et al. (2006) highlight the hedonic consumption tendency as an important mediator in determining fashion-oriented impulse buying behaviour. In addition, Park et al. (2012) confirm that hedonic web browsing has a positive effect on e-impulse buying. Likewise, Madhavaram and Laverie (2004) find that positive hedonic experiences are related to impulse purchases online.

The topic of purchasing behaviour of Croatian consumers in online retailing environment is a rather underresearched area. Given the specific nature of e-retailing environment, it is of the utmost importance for online retailers and marketers to better understand online consummers' behaviour. Consequently, the main research objective of the paper is to determine the influence of impulsiveness on counsumers' attitudes and intentions towards online purchasing. In that context, the perceptions of 240 Croatian consumers from the Dubrovnik-Neretva County are analysed. To achieve the research objectives, this paper is divided into five sections. Following the introduction, the second section provides the selected literature review on online purchasing behaviour. Research methodology is discussed in the third section, while the fourth presents research results and the discussion of findings. The final section of the paper draws cetain conclusions.

\section{Literature review}

Examining online shopping intentions is a wide, complex area covering a number of different elements. Consequently, it is argued that offline and online store perceptions directly influence online purchase intention (Verhagen \& van Dolen, 2009). According to Brown et al. (2003), factors that influence purchase intentions include product type, prior purchase, and, to a lesser extent, gender. Moreover, impulse purchase orientation, prior online purchase experience and online trust have significant impact on the customer purchase intention (Thamizhvanan \& Xavier, 2013). Likewise, Jayawardhena et al. (2007) assert that prior purchase and gender have a significant effect on purchase intention. As regards the relationship between past online purchases and purchasing intentions, the results show that past purchasing predicts intentions to purchase (Weisberg et al., 2011). Nevertheless, perceived value has a positive effect on purchase intention (Wang et al., 2013). Research results also indicate that individualism is the only culture dimension to have a significant effect on purchase intention (Moon et al., 2008). On the other hand, Hong and Cho (2011) highlight attitudinal loyalty as an important determinant of purchase intentions in B2C e-marketplaces.

Security and privacy issues are of the utmost importance in electronic retailing. These mainly refer to the risks associated with online retailing, such as revealing personal information, the possibility of credit card fraud and the inability to touch the products before purchasing. In that sense, e-vendors have adjusted their online shopping systems to convince customers that vendors and systems are trustworthy (Jarvelainen, 2007). In that sense, Van Noort et al. (2008) argue that online safety cues both lower consumers' risk perceptions and engender more favorable attitudes and intentions, depending on the regulatory focus.

Furthermore, online trust can discourage online consumers from online retailing and can influence purchase intentions. Schlosser et al. (2006) emphasize the role of trust in predicting online purchase intentions. Moreover, Mukherjee and Nath (2007) argue that trust and commitment are the central tenets in building successful long-term relationships in the online retailing context and that behavioural intentions of customers are consequences of both trust and commitment. Trust in the vendor/website's ability positively affects the intention to get information and the purchase intention (Lu et al., 2010). Similarly, consumer trust mediates the positive influence of pleasure on purchase intention (Ding \& Lin, 2012). Regarding the relationship between trust and habit, it is found that trust has lower effect than habit on repeat purchase intention whils habit will negatively moderate the impact of trust on repeat purchase intention (Chiu et al., 2012). Risk perceptions regarding Internet privacy and security have been identified as important issues for both new and experienced users of Internet technology (Miyazaki \& Fernandez, 2001). Online store image impacts purchase intentions indirectly by decreasing risk perceptions (Aghekyan-Simonian et al., 2012). In that context, privacy concern has a negative influence on online spending, i.e., people who are concerned about privacy spend less on online purchases (Akhter, 2012). 
Another important issue refers to understanding customers' repurchase intentions in online shopping. In that context, the findings reveal that trust, perceived ease of use, perceived usefulness and enjoyment are significant positive predictors of customers' repurchase intentions (Chiu et al., 2009). As regards the effects of consumers' perception of online retailers' ethical behaviour on consumer purchase and revisit intentions it was found that perceived ethics of an Internet retailer's website significantly affected consumers' trust and attitudes to the retailer's website that eventually had positive impacts on purchase and revisit intentions (Limbu et al., 2012). Furthermore, to enhance customer purchase intentions, online stores should develop marketing strategies to better address the trustworthiness, reliability, and responsiveness of web-based services (Lee \& Lin, 2005).

As regards different forms of unregulated consumer behaviour, impulsive, compulsive and addictive buying are present on the Internet (LaRose and Eastin, 2002). Online medium facilitates impulse buying behaviour and impulsive buying opportunities which are rising significantly due to economic and social changes (Kervenoael et al., 2009). In their analysis of external and internal trigger cues of impulse buying online, Dawson and Kim (2009) found a positive correlation between a person's impulse buying tendency and online impulse buying behaviour, as well as between a person's affective state and online buying behaviour. Similarly, the findings from the study by Dawson and Kim (2010) suggest that the amount of external trigger cues of impulse buying may be a factor that encourages online impulse purchases and, consequently, affects a retailer's profitable success.

In regard to online environment, it is important to take into consideration some online environment cues affecting customer purchase intention, such as web site quality and web site brand. Website attitudes positively influence brand attitudes, which in turn positively influences purchase intentions (Hwang et al., 2011). Online atmospherics such as graphics, colors, and links have an impact on customer emotions such as pleasure and arousal, both of which have subsequent effects on intention (Koo \& Ju, 2010). In that context, the study by Harris and Goode (2010) revealed that consumers' interpretations of online environments exerted a powerful influence over trust and purchase intentions. The findings confirmed that web-site quality and web site brand affected consumers' trust and perceived risk, and in turn, consumer purchase intention. Similarly, evidences suggested that web-site trust, web-site satisfaction, web-site awareness, and overall customer satisfaction all influenced the online purchase intention (Bai et al., 2008). In examining roles of e-shopping quality and experiential e-shopping motives it was found that web site content/functionality and atmospheric/experiential quality had significant impact on e-shopping satisfaction contributing to e-shopping intention, while privacy/security and customer service had significant impact on e-shopping intention but not on e-shopping satisfaction (Ha \& Stoel, 2012).

\section{Research methodology}

The data was collected through survey questionnaire using the purposive sample of 240 consumers from the DubrovnikNeretva County. The empirical survey was carried out in March and April 2012. The survey questionnaire consisted of 29 statements and questions. The first section of the questionnaire was related to the demographic as well as socioeconomic variables. The second section of the questionnaire included questions regarding the features of online consumers. The third section of the questionnaire included online impulsive measurement scale to determine the impulsive behaviour of online consumers. The scale of measurement was ordinal with degrees from 1 to 5 , where respondents expressed their degree of agreement or disagreement with the statement (1=completely disagree, $5=$ strongly agree).

Before using the factor analysis, the reliability of Cronbach's alpha coefficient of online impulsive measurement scale was determined. Moreover, the factor analysis (principal component analysis) was used in order to reduce a larger number of variables to a smaller number of factors. Collected data was analysed using computer software package for processing qualitative and quantitative data of social research - SPSS 20. In this paper, various multivariate statistical analyses were used such as factor analysis and correlation analysis.

\section{Findings and discussion}

Before employing multivariate statistical approach it is necessary to determine the reliability of online impulsive measurement scales. Table 1 shows the coefficient Cronbach's alpha of online impulsive measurement scale.

Table 1. Reliability of online impulsive measurement scale 


\begin{tabular}{|c|c|}
\hline Number of variable & Cronbach's Alpha \\
\hline 7 & .832 \\
\hline
\end{tabular}

Source: Research findings ( $\mathrm{N}=240)$

The results show high reliability Cronbach's alpha coefficient (0.832) of online impulsive measurement scale. The following table shows the results of the statistical tests $\mathrm{KMO}$ and Bartlett test of sphericity.

Table 2. Kaiser-Meyer-Olkin test and Bartlett's test of sphericity of online impulsive measurement scale

\begin{tabular}{|c|c|c|}
\hline \multicolumn{2}{|c|}{ Kaiser-Meyer-Olkin Measure of Sampling Adequacy } & .809 \\
\hline Bartlett's Test of Sphericity & Approx. Chi-Square & 595.234 \\
\hline Df & 21 \\
\hline Sig. & .000 \\
\hline
\end{tabular}

Source: Research findings ( $\mathrm{N}=240)$

The result of the Kaiser-Meyer-Olkin test was very high $(\mathrm{KMO}=0.809)$ and Bartlett test of sphericity was statistically significant $(a \leq 0.05)$. Hence, the adequacy of the sample was established and the scale was uni-dimensional. Principles component factor analysis with varimax rotation method and Kaiser-Guttman criteria was performed on the data. According to the Kaiser-Guttman criteria the model can include only the factors with eigenvalues above 1. Consequently, two components or variables with eigenvalues above 1 were extracted.

Based on the results, it is evident that $50.25 \%$ of the total variance is explained by Factor 1 and $15.46 \%$ of the total variance is explained by Factor 2. Together, these two variables explain more than $65 \%$ of the total variance. Rotated component matrix was obtained by further analysis. Factor loadings vary between 0.559 and 0.869 indicating significant loading of the manifest variables in explaining the extracted factors.

The purpose of factor analysis is achieved and the interpretation of factors is satisfactory. Therefore, the results of factor analysis for online impulsive scale indicate excellent properties of convergent and discriminant validity. As per the content of the statements, it can be concluded that the Factor 1 is related to the impulsiveness feature of the respondents and it is named the impulsiveness factor, whilst the Factor 2 is related to fun and entertainment and it is, therefore, named the recreational factor.

Relation between factors and consumers attitudes and intentions towards online purchase were examined by using Spearman's rank correlation. Correlation analyses determine the relation direction, strength as well as the significant of the relation. The further processing of data is approached by using the Spearman's correlation coefficient. Table 3 shows the results of correlation matrix between factor impulsiveness and consumers attitudes towards purchasing online.

Table 3. Correlation matrix between factor impulsiveness and consumers attitudes towards online purchase

\begin{tabular}{|c|c|c|c|c|}
\hline & $\begin{array}{c}\text { Online purchasing is a } \\
\text { good thing }\end{array}$ & $\begin{array}{c}\text { Online purchasing is } \\
\text { necessary nowadays }\end{array}$ & $\begin{array}{c}\text { Online purchasing is } \\
\text { favourable for consumers }\end{array}$ & $\begin{array}{c}\text { I like purchasing } \\
\text { online }\end{array}$ \\
\hline \multirow{2}{*}{ Impulsiveness } & .091 & .105 & $.123^{*}$ & $.211^{* *}$ \\
\cline { 2 - 5 } & .080 & .033 & .029 & .001 \\
\hline
\end{tabular}

Source: Research findings ( $\mathrm{N}=240)$

Correlation analysis results indicate the existence of the partial correlation between the impulsiveness and consumer attitudes toward purchasing online. The last two items, which are statistically significant with a positive direction, suggest that impulsiveness of online consumers positively influences on perception towards purchasing online because consumers consider purchasing online more convenient than other, traditional forms of purchase.

Based on these findings the reasons for the significant statistical incoherence and weak relation could be numerous. However, due to a lower correlation coefficient there is a possibility of negative feelings that occur during the impulsive online purchase. In that context, it was found that impulsive buying may stimulate emotional conflict (Punj, 
2011), buyers' dissatisfaction and regret (Wood, 1998) as well as self-conscious emotions, such as guilt and shame (Yi \& Baumgartner, 2011). The next table shows the correlation matrix between recreational factor and consumers attitudes towards online purchase by using Spearman's correlation coefficient.

Table 4. Correlation matrix between recreational factor and consumers attitudes towards online purchase

\begin{tabular}{|c|c|c|c|c|}
\hline & $\begin{array}{c}\text { Online purchasing is a } \\
\text { good thing }\end{array}$ & $\begin{array}{c}\text { Online purchasing is } \\
\text { necessary nowadays }\end{array}$ & $\begin{array}{c}\text { Online purchasing is } \\
\text { favourable for consumers }\end{array}$ & $\begin{array}{c}\text { I like purchasing } \\
\text { online }\end{array}$ \\
\hline $\begin{array}{c}\text { Recreational } \\
\text { factor }\end{array}$ & $.376^{* *}$ & $.255^{\star *}$ & $.233^{* *}$ & $.490^{* *}$ \\
\cline { 2 - 5 } & .000 & .000 & .000 & .000 \\
\hline
\end{tabular}

${ }^{* *}$ Correlation is significant at the 0.01 level

Source: Research findings ( $N=240)$

Correlation analysis indicates a statistically significant but weak relation between recreational factor and consumers attitudes towards online purchase. Values of correlation coefficient show the positive direction in range of $0.233<r>0.490$, indicating that recreational factors positively influence on consumer's attitudes towards online purchase.

These results show that online consumers who actively purchase have a positive attitude towards purchasing online as they consider this form of purchase desirable. This attitude also encourages positive emotions and creates a positive shopping experience. The following table shows the results of correlation analysis between impulsiveness and recreational factor and consumers intentions towards online purchase.

Table 5. Correlation matrix between impulsiveness and recreational factor and consumers intentions towards purchasing online

\begin{tabular}{|c|c|}
\hline & Consumers' intentions towards purchasing online \\
\hline \multirow{2}{*}{ Impulsiveness } & .063 \\
\cline { 2 - 3 } & .166 \\
\hline \multirow{2}{*}{$\begin{array}{c}\text { Recreational } \\
\text { factor }\end{array}$} & $.368^{\star *}$ \\
\cline { 2 - 2 } & .000 \\
\hline
\end{tabular}

** Correlation is significant at the 0.01 level

Source: Research findings $(\mathrm{N}=240)$

Correlation analysis indicates that there is no statistically significant relation between impulsiveness and consumers intentions towards purchasing online i.e. impulsiveness of consumers will not influence on online purchase intention. On the other hand, the above findings suggest that a positive, statistically significant and moderately strong relation exists between recreational factor and consumers' intentions towards online purchase. The correlation coefficient between recreational factor and consumers intentions towards online purchase indicates that consumers who purchase only due to recreational reasons will be more inclined to make an online purchase in the future.

\section{Concluding Remarks}

With the increasing importance of online shopping, understanding consumers' online purchasing behaviour and the motives affecting consumers' online purchase intentions has become an important issue for academics and practitioners.

This paper sought to provide a better understanding of purchasing behaviour of Croatian customers in an electronic commerce environment. It contributes to the existing literature on impulsive online buying behaviour by providing new insights into Croatian consumers' attitudes towards online purchasing and their intentions to purchase products at online stores.

Based on a sample of 240 Croatian customers, research results indicate that Croatian online consumers are influenced by two major factors, namely impulsiveness and recreational factor. Based on the research results, it can be concluded that impulsiveness of online consumers positively influences on perceptions towards purchasing online because they consider purchasing online more convenient than traditional forms of purchase. Moreover, online 
consumers who actively purchase have a positive attitude towards purchasing online as they consider this purchase desirable. No statistically significant relation was found between impulsiveness and consumers intentions towards purchasing online i.e. impulsiveness of consumers will not influence on online purchase intention. On the other hand, recreational factors also positively influence on consumer's attitudes towards online purchase. Furthermore, as regards recreational factor and consumers intentions towards online purchase, consumers who purchase only due to recreational reasons will be more inclined to online purchase in the future.

These findings may be useful to online retailers, as well as marketers and practitioners to recognize and understand the determinants of purchasing behaviour of Croatian consumers, in particular their attitudes and intentions towards online purchasing. Furthermore, by taking into consideration these determinants e-retailers and marketers can foster more positive attitudes and online purchase intentions. However, the findings should be considered in the light of their limitations. First of all, in regards to a sample selection, the research was conducted in one Croatian county, which possibly limits the representativeness of the sample and the generalisation of the findings. The future research sample should be extended by including other Croatian counties and conducting the research over a longer period of time. In that way, certain similarities and differences of Croatian customer online purchasing behaviour could be identified.

\section{References}

Aghekyan-Simonian, M., Forsythe, S., Kwon, W. S. \& Chattaraman, V. (2012). The role of product brand image and online store image on perceived risks and online purchase intentions for apparel. Journal of Retailing and Consummer Services, 19(3), 325-331.

Akhter, S. H. (2012). Who spends more online? The influence of time, usage variety, and privacy concern on online spending. Journal of Retailing and Consumer Services, 19(1), 109-115.

Bai, B., Law, R. \& Wen, I. (2008). The impact of website quality on customer satisfaction and purchase intentions: Evidence from Chinese online visitors. International Journal of Hospitality Management, 27(3), 391-402.

Bhasker, B. (2006). Electronic Commerce: Framework, Technologies and Applications. (2nd ed.) New Delhi: Tata McGraw-Hill Publlishing Company Limited

Bridges, E. \& Florsheim, R. (2008). Hedonic and utilitarian shopping goals: The online experience. Journal of Business Research, 61(4), 309-314.

Brown, M., Pope, N. \& Voges, K. (2003). Buying or browsing? An exploration of shopping orientations and online purchase intention. European Journal of Marketing, 37(11/12), 1666-1684.

Chen, Y.-H. \& Barnes, S. (2007). Initial trust and online buyer behaviour. Industrial Management \& DataSystems, 107(1), 21-36.

Chiu, C.-M., Chang, C.-C., Cheng, H.-L. \& Fang, Y.-H. (2009). Determinants of customer repurchase intention in online shopping. Online Information Review, 33(4), 761-784.

Chiu, C.-M., Hsu, M. H., Lai, H. \& Chang, C.-M. (2012). Re-examining the influence of trust on online repeat purchase intention: The moderating role of habit and its antecedents. Decision Support Systems, 53(4), 835-845.

Dawson, S. \& Kim, M. (2009). External and internal trigger cues of impulse buying online. Direct Marketing: An International Journal, 3(1), 20-34.

Dawson, S., Kim, M. (2010). Cues on apparel web sites that trigger impulse purchases. Journal of Fashion Marketing and Management, 14(2), 230-246.

Dennis, C., Fenech, T., \& Merrilees, B. (2004). E-retailing. (1st ed.) Oxon: Routledge

Ding, C. G. \& Lin, C.-H. (2012). How does background music tempo work for online shopping? Electronic Commerce Research and Applications, 11(3), 299-307.

Floh, A. \& Madlberger, M. (2013). The role of atmospheric cues in online impulse-buying behavior. Electronic Commerce Research and Applications. Retrieved on June 18, 2013 from the following World Web Site: http://www.sciencedirect.com/science larticle/pii/S1567422313000410

Ha, S. \& Stoel, L. (2012). Online apparel retailing: roles of e-shopping quality and experiential e-shopping motives. Journal of Service Management, 23(2), 197-215.

Harris, L. C. \& Goode, M. M. H. (2010). Online servicescapes, trust, and purchase intentions. Journal of Services Marketing, 24(3), 230243.

Hong, I. B. \& Cho, H. (2011). The impact of consumer trust on attitudinal loyalty and purchase intentions in B2C e-marketplaces: Intermediary trust vs. seller trust. International Journal of Information Management, 31(5), 469-479.

Hwang, J., Yoon,Y.-S. \& Park, N.-H. (2011). Structural effects of cognitive and affective responses to web advertisement, website and brand attitudes, and purchase intentions: The case of casual-dining restaurants. International Journal of Hospitality Management, $30(4), 897-907$.

Jarvelainen, J. (2007). Online purchase intentions: An empirical testing of a multiple-theory model. Journal of Organizational Computing and Electronic Commerce, 17(1), 53-74.

Jayawardhena, C., Wright, L. T. \& Dennis, C. (2007). Consumers online: intentions, orientations and segmentation. International Journal of Retail and Distribution Management, 35(6), 515-526.

Kau, A. K., Tang, Y. E. \& Ghose, S. (2003). Typology of online shoppers. Journal of Consumer Marketing, 20(2), 139-156. 
Kervenoael, R., Aykac, D. S. \& Palmer, M. (2009). Online social capital: Understanding e-impulse buying in practice. Journal of Retailing and Consumer Services, 16(4), 320-328.

Koo, D.-M. \& Ju, S.-H. (2010). The interactional effects of atmospherics and perceptual curiosity on emotions and online shopping intention. Computers in Human Behavior, 26(3), 377-388.

LaRose, R. \& Eastin, M. S. (2002). Is Online Buying Out of Control? Electronic Commerce and Consumer Self-Regulation. Journal of Broadcasting \& Electronic Media, 46(4), 549-564.

Lee, G.-G. \& Lin, H.-F. (2005). Customer perceptions of e-service quality in online shopping. International Journal of Retail \& Distribution Management, 33(2), 161-176.

Limbu, Y. B., Wolf, M. \& Lunsford, D. (2012). Perceived ethics of online retailers and consumer behavioral intentions: The mediating roles of trust and attitude. Journal of Research in Interactive Marketing, 6 (2), 133-154.

Lu, Y., Zhao, L. \& Wang, B. (2010). From virtual community members to C2C e-commerce buyers: Trust in virtual communities and its effect on consumers' purchase intention. Electronic Commerce Research and Applications, 9(4), 346-360.

Madhavaram, S. R. \& Laverie, D. A. (2004). Exploring Impulse Purchasing on the Internet. Advances in Consumer Research, Vol. 31, 59-66.

Martin, H. S. \& Herrero, A. (2012). Influence of the user's psychological factors on the online purchase intention in rural tourism: Integrating innovativeness to the UTAUT framework. Tourism Management, 33(2), 341-350.

Miyazaki, A. D. \& Fernandez, A. (2001). Consumer Perceptions of Privacy and Security Risks for Online Shopping. Journal of Consumer Affairs, 35(1), 27-44.

Monsuwe, T. P., Dellaert, B. G. C. \& Ruyter, K. (2004). What drives consumers to shop online? A literature review. International Journal of Service Industry Management, 15(1), 102-121.

Moon, J., Chadee, D. \& Tikoo, S. (2008). Culture, product type, and price influences on consumer purchase intention to buy personalized products online. Journal of Business Research, 61(1), 31-39.

Mukherjee, A. \&, Nath, P. (2007). Role of electronic trust in online retailing: A re-examination of the commitment-trust theory. European Journal of Marketing, 41(9/10), 1173-1202.

Park, E. J., Kim, E. Y. \& Forney, J. C. (2006). A structural model of fashion-oriented impulse buying behaviour. Journal of Fashion Marketing and Management, 10(4), 433-446.

Park, E. J., Kim, E. Y., Funches, V. M. \& Foxx, W. (2012). Apparel product attributes, web browsing, and e-impulse buying on shopping websites. Journal of Business Research, 65(11), 1583-1589.

Punj, G. (2011). Impulse buying and variety seeking: Similarities and differences. Journal of Business Research, 64(7), 745-748.

Rohm, A. J. \& Swaminathan, V. (2004). A typology of online shoppers based on shopping motivations. Journal of Business Research, 57(7), 748-757.

Salo, J. \& Karjaluoto, H. (2009). A conceptual model of trust in the online environment. Online Information Review, 31(5), 604-621.

Schlosser, A. E., White, T. B. \& Lloyd, S. M. (2006). Converting Web Site Visitors into Buyers: How Web Site Investment Increases Consumer Trusting Beliefs and Online Purchase Intentions, Journal of Marketing, Vol. 70, 133-148.

Shim, S., Eastlick, M. A., Lotz, S. L. \& Warrington, P. (2001). An online prepurchase intentions model: The role of intention to search. Journal of Retailing, 77(3), 397-416.

Thamizhvanan, A. \& Xavier, M. J. (2013). Determinants of customers' online purchase intention: an empirical study in India. Journal of Indian Business Research, 5(1), 17-32.

van der Heijden, H., Verhagen, T. \& Creemers, M. (2003). Understanding online purchase intentions: contributions from technology and trust perspectives. European Journal of Information Systems, Vol. 12, 41-48.

Van Noort, G., Kerkhof, P. \& Fennis, B. M. (2008). The persuasiveness of online safety cues: The impact of prevention focus compatibility of Web content on consumers' risk perceptions, attitudes, and intentions. Journal of Interactive Marketing, 22(4), 5872.

Verhagen, T. \& van Dolen, W. (2009). Online purchase intentions: A multi-channel store image perspective. Information \& Management, 46(2), 77-82.

Vazquez, D. \& Xu, X. (2009). Investigating linkages between online purchase behaviour variables. International Journal of Retail and Distribution Management, 37(5), 408-419.

Wang, Y.-S., Yeh, C.-H. \& Liao, Y.-W. (2013). What drives purchase intention in the context of online content services? The moderating role of ethical self-efficacy for online piracy. International Journal of Information Management, 33(1), 199-208.

Weisberg, J., Te'eni, D. \& Arman, L. (2011). Past purchase and intention to purchase in e-commerce: The mediation of social presence and trust. Internet Research, 21(1), 82-96.

Weitz, B. A. (2010). Electronic Retailing. In Krafft, M. \& Mantrala, M. K. (Eds.), Retailing in the 21st Century: Current and Future Trends, (pp. 357-371). Springer-Verlag Berlin Heidelberg

Wood, M. (1998). Socio-economic status, delay of gratification, and impulse buying. Journal of Economic Psychology, 19(3), 295-320.

Yi, S. \& Baumgartner, H. (2011). Coping with guilt and shame in the impulse buying context. Journal of Economic Psychology, 32(3), 458-467. 
